\section{Research in Australian Sea Fisheries}

Prof. W. J. Dakin in his R. M. Johnston Memorial Lecture (Pap. and Proc. Roy. Soc. Tasmania for 1934 (1935)) gave a brief survey of various fisheries in all parts of the world and the methods of investigation. Then he proceeded to outline the needs of Australian fisheries. A beginning has been made in different directions, notably with age determinations and biology of the important commercial fish of New South Wales, the tiger flathead. Investigations are also being made into the life-histories of certain fishes and their eggs and larvæ, especially the Australian pilchard. Among the plankton studies one of special importance relates to the biology of the peneid prawns, the life-history of which is now being worked out by Prof. Dakin. The best-known prawns there are the king prawn, Peneus plebejus, and the school prawn, Penoeopsis macleayi. During the winter, few or no prawns can be taken with nets and those captured are usually small; but in spring there comes a time when the king prawn can be caught in the lakes, and those first taken are small and come from the end farthest from the sea. Later, larger specimens are caught and then enormous outflows or 'runs' of large prawns take place on dark nights. The prawns flock to the entrance connecting the lake with the sea and can be captured in huge quantities. These large prawns are all immature and not quite fully grown, and it is now known that they are migrating to the sea in order to breed there. The eggs are shed in the open ocean and hatch as nauplii, the young migrating into the lakes there to feed and grow. The large prawns migrating to the sea from the lake are less than a year old-a most interesting life-history, and published here for the first time. Penceopsis monoceros appears to be exceptional in laying its eggs in the Swan River at Perth.

\section{Forestry in New Zealand}

AN important circular (No. 35, "New Zealand Official Year Book", 1935. Government Printer, Wellington, New Zealand) by Mr. A. D. McGavock, director of forestry, deals with the present policy of the Government on the subject of the forests and forestry in New Zealand. The circular, which merits a careful perusal by all interested in the development of a forest policy for the Empire as a whole, accords full recognition to the importance of the remaining indigenous forests to the future well-being of the country, and emphasises the importance among other species of conserving the remaining Kauri forests. "It is the intention of the State Forest Service," says the circular, "to bring the whole of the national Kauri forests under management plans which will ensure their perpetuation for all time." The general forest policy in New Zealand may be stated as the perpetuation of the indigenous forests and the provision of a supplementary exotic-forest capital which, by rapid growth, will eke out the supplies of indigenous timber and bridge the gap between the exhaustion of the over-mature indigenous forests, which otherwise would occur, and their conversion into healthy production forests. With the establishment of the exotic plantations now approaching completion, it will be possible to give proper attention to the sylvicultural treatment of the indigenous forests. The timber supply position of the future envisages a balanced yield from both exotic and indigenous forests, and the future alone will determine the relative importance of the two sources of supply. The chief remaining source of anxiety is the gigantic problem of undertaking successfully the thinnings now becoming necessary in the enormous area of State and privately owned plantations, aggregating some 672,000 acres; for an adequately trained staff of sufficient strength to cope with this delicate work does not appear to exist.

\section{Oxidation and Scaling of Heated Solid Metals}

For some time past the Metallurgical Research Board of the Department of Scientific and Industrial Research has been devoting special attention to the oxidation and scaling of heated metals. A critical survey of existing knowledge on this subject, the importance of which in the treatment, fabrication and use of metals needs no emphasising, is now avail. able ("Review of Oxidation and Scaling of Heated Solid Metals". London: H.M. Stationery Office, 1935. 2s. 6d. net). Although the development of heat-resisting alloys has brought about considerable improvements, much still remains to be done before the troubles and losses due to the oxidation of metals are completely eliminated. The six sections of the review, each of which is contributed by a recognised authority, deal with the theoretical aspects of oxidation, the constitution and formation of scale on ferrous alloys, the quantitative consideration of the oxidation of iron and steel at elevated temperatures, the oxidation of non-ferrous metals and the industrial and practical aspects of the subject. In addition to providing a quite considerable amount of important information for immediate use, the review focuses attention on the problems upon which further research is required and will be found to be of the greatest assistance to other investigators of the same or cognate subjects.

\section{History and Uses of Solders}

Bulletris No. 2, issued by the International Tin Research and Development Council, contains a very interesting account of the history and modern uses of solders in a wide variety of forms. The pamphlet of some fifty pages, which has been prepared by D. J. Macnaughtan, director of research, and Dr. E. S. Hedges, is available free of charge, to all who are interested in the now numerous industries in which solder is used, from the International Tin Research and Development Council, Manfield House, 378 Strand, London, W.C.2. In 1933, 18,000 tons of tin was employed in the manufacture of solders, of which 5,000 tons was used by the motor-car industry and 4,500 tons by the canning and box-making trades. The bulletin indicates the rapid progress which is being made in the use of soldered joints in air conditioning, central heating and refrigerating plant as well as in the electrical industry. The 
ingenious types of machinery which have been designed for the soldering of parts in the motor-car radiator, and in the closing of tin plate cans, now produced in thousands of millions a year, are described. The compositions and physical properties of solders of representative grades are discussed and the reasons for the suitability of each kind for special purposes are shown. The importance of using the right type of flux is explained and practical details of the fluxing and tinning of a large number of metals and alloys are given. Not the least valuable portion of the bulletin is the appendix, in which are given references to a large number of the more important books, papers and specifications dealing with solders and the production of soldered joints.

\section{Braking Efficiency of Modern Motor-Cars}

AN abstract of a speech made by Prof. R. A. Moyer at the Annual Safety Congress, held at the Iowa State College, has been issued by Science Service, Washington, D.C. Prof. Moyer considers that on ordinary roads the present-day braking power of motor-cars when driven at their highest speeds is insufficient, and that they are decidedly unsafe. Safety lies mainly in providing low stopping distances. To provide the same stopping distance when travelling at 60 miles an hour as at 40 miles an hour requires brakes two and a half times as powerful. In Prof. Moyer's opinion, to maintain traffic speeds at about 45 miles an hour on open stretches of road would eliminate many of the risks arising from high speed. A study of traffic statistics shows that half the risk of accident would be eliminated if cars were forbidden to run at more than 55 miles an hour. If speeds greater than this are necessary, it would be far cheaper and probably equally safe to use an aeroplane. Prof. Moyer points out that Sir Malcolm Campbell needed a 2,500 horse-power motor to average $\mathbf{3 0 0}$ miles an hour on the salt beds of Utahprobably the most perfect race course in the world. On the other hand, an aeroplane with a 1,000 horsepower motor can reach 350 miles an hour in the air.

\section{The British Accumulator Industry}

WHEN the National Grid was established in Great Britain in 1926 and the Electricity Commissioners adopted alternating current as the standard for distribution, many thought that it would affect adversely the electric accumulator industry. In an address delivered to the Institution of Electrical Engineers by E. C. McKinnon on October 22, it is pointed out that this is not the case. The industry is flourishing, and accumulators have rendered practicable many new electrical applications. For submarines they are essential, and the evolution of the submarine battery in thirty-five years has led to increasing its average life threefold and trebling its capacity for a given volume. Since the first automobile self-starter battery came into service in 1911, numerous current consuming 'gadgets' have boen added to the electrical equipment of the car, but in spite of this the present-day starter battery is much lighter, occupies much less space and gives a long life. Like the submarine, batteries for air- craft have called for much ingenuity in design. The cells for a large submarine may weigh $1 \frac{1}{2}$ tons each and their number ranges from 100 to more than 300 . Each cell has a volume of about 20 cubic feet and has to be lowered intact into the submarine. An aeroplane battery has to be much lighter, its usual weight being about 46 pounds and its volume about 700 cubic inches. To me日t the demands of aerobatics it must be absolutely unspillable in the inverted position. This is done by an ingenious hydrostatic device, and not by using a jellified electrolyte. There is a large demand for accumulators for automatic telephone purposes and for train 'lighting and cooking'. One of the widest applications for batteries nowadays is for emergency and standby purposes. A battery can ensure continuity of illumination for traders during busy periods, when a 'black-out' would be serious, and in hospitals. It is interesting to notice also that for many auxiliary services in connexion with the National Grid supply, there is a considerable demand for accumulators.

\section{Japan and Electric Communication}

Electrical communication industries are developing very rapidly in Japan. There are a million telephones in use, and two million homes have radio receiving sets. The Institute of Telephone and Telegraph Engineers has now five thousand members, and publishes a valuable technical journal every month. It has been decided to increase its usefulness by publishing every quarter an English edition of it. In the first English journal, the president of the Institute, Mr. T. Akiyama, says that their present knowledge of the technique of electrical communications has been obtainod largely from abroad, and that it is their duty to bring to the notice of foreign countries their own achievements in research and so repay the friendship shown to them through many years. By so doing it is hoped to contribute to the general advance of civilisation. It is stated that limited land and over-population have placed Japan in a position in which the nation cannot exist on agriculture alone; it is forced to turn to manufacturing industry for its welfare. At the present time, approximately 40 per cent of the Japanese population is engaged in commerce and industry. Japan is the boundary line between Asia and the Pacific Ocean. It is the duty of Japan to provide national and international communication networks so as to help to harmonise the Oriental and the Western civilisations. The development of radio communication in Japan has been largely due to their own initiative, and practically all the transmitting apparatus is of their own manufacture. There are twenty-five broadcasting stations which are run by a company under the supervision of the Government. They are all interconnected by wiro lines. The Japanese director-gonoral of onginoering says that their ideal is to help the fusion of cultures by keeping in constant touch with the other nations of the world. The journal, Nippon Electrical Communication Engineering, is a useful contribution to technical literature. 